\title{
Preliminary evidence for green, brown and black worlds in tropical western Africa during the Middle and Late Pleistocene
}

\author{
William D. Gosling, Crystal N.H. McMichael, Zoë Groenewoud \& Eleonora \\ Roding \\ Institute for Biodiversity and Ecosystems Dynamics, University of Amsterdam, \\ Amsterdam, The Netherlands
}

Charlotte S. Miller

Leeds Trinity University, Leeds, United Kingdom

Adele C.M. Julier

Plant Conservation Unit, University of Cape Town, Cape Town, South Africa

\begin{abstract}
Modern ecological studies indicate that the degree of openness in African vegetation cover is determined, in part, by the presence of herbivores and fire as consumers of vegetation. Where herbivores are the dominant consumer of vegetation the resultant open state is described as a 'brown' world. Where fire is the dominant consumer of vegetation the resultant open state is described as a 'black' world. While if neither consumer is dominant then a more closed canopy states arises that is described as a 'green' world. Here we use palaeoecological data obtained from Lake Bosumtwi (Ghana) to characterize green, brown, and black worlds during two short sections of around 1000 years each, deposited around 200,000 and 100,000 years ago (Middle and Late Pleistocene). We characterize the vegetation cover using pollen and phytoliths, herbivory using Sporormiella and fire using micro-charcoal. We find that during c. 1000 years of the Middle Pleistocene fire was the major consumer of vegetation, while during $c .1000$ years in the Late Pleistocene herbivores were relatively more important consumers of vegetation. We therefore suggest that the Middle Pleistocene section represents a black world, while in the Late Pleistocene section we capture a combination of green, brown and black worlds. The duration of these states seems to range from centuries to millennia and transitions are observed to occur in both an abrupt and a stepwise fashion. These preliminary data demonstrate how palaeoecological information can be used to gain insights into past landscape scale processes over thousands of years. Further work is required to test the robustness of these findings and to provide a higher temporal resolution to aid the link with modern ecological studies.
\end{abstract}




\subsection{INTRODUCTION}

The theory of 'alternative stable states' proposes that biotic and abiotic feedbacks can determine the composition and structure of an ecosystem regardless of external factors, such as climate (May 1977; Scheffer et al. 2001). The presence of herbivory and fire activity in African landscapes has long been suggested to be a key factor in determining the openness of the vegetation cover (Stebbing 1937). To characterize the role of herbivory and fire as mechanisms determining the degree of vegetation openness (alternative stable state) William Bond developed the concept of 'green', 'brown' and 'black' worlds (Figure 1; Bond 2005; Bond 2019). This 'multi-coloured' world model comprises three vegetation states based on differences in herbivory and fire as consumers of vegetation: (i) a 'green' world where consumers (herbivores and fires) are at sufficiently low occurrence levels as to not influence vegetation growth and consequently vegetation cover is more closed and primarily controlled by plant resource acquisition, (ii) a 'brown' world where an abundance of herbivores consuming seeds, seedlings and saplings means a more open vegetation structure, and (iii) a 'black' world where the frequent occurrence of fires consuming vegetation means a more open vegetation structure.

Modern studies in African savannas have demonstrated that herbivory and fire play an important role in the complex interactions that determine vegetation openness (Sankaran et al. 2008) and consequently the regulation of both are routinely used in landscape management (Roques et al. 2001). Evidence from modern exclosure experiments has demonstrated that the removal of animals from ecosystems can result in changes to vegetation state on timescales of years to decades (e.g. Riginos et al. 2012; Staver et al. 2009). While the manipulation of fire regimes, through experimental burns and fire suppression initiatives, have demonstrated vegetation state can also be altered through these processes on decadal timescales (e.g. Enslin et al. 2000; King et al. 1997). Over the longer-term (>100s of years) palaeoecological data have revealed that past changes in herbivory and fire activity have altered African vegetation composition and structure (e.g. Ivory and Russell 2016; Runcia et al. 2009; Shanahan et al. 2016). Palaeoecological data therefore provide an opportunity to search for evidence of the green, brown and black worlds proposed by Bond (2005), test the timescales of their stability, and discover how transitions between them occur.

Based on Bond's multi-coloured world model it can be suggested that the addition, or subtraction, of either herbivory or fire as a consumer of vegetation in a landscape would result in a shift in the degree of openness (Figure 1). Here we use palaeoecological data to parametrize vegetation openness (Poaceae pollen/phytoliths), herbivory (Sporormiella) and fire (charcoal) to provide 'snap shots' of vegetation states in tropical western Africa during the Middle and Late Pleistocene. We use these data to identify periods of time when consumers (both animals and fires) did, and did not, exert a dominant control over the vegetation openness.

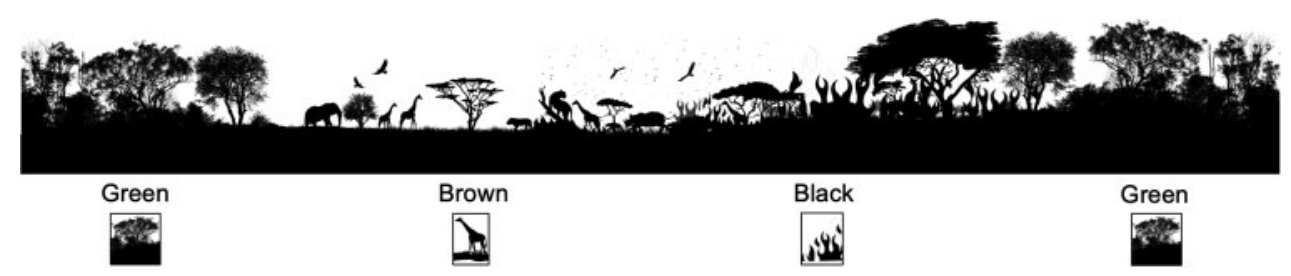

Figure 1. Conceptual panorama of vegetation change across an African landscape dependent on the dominant consumer of vegetation. Green $=$ absence of consumers. Brown $=$ herbivores are the dominant consumers. Black $=$ fire is the dominant consumer. 


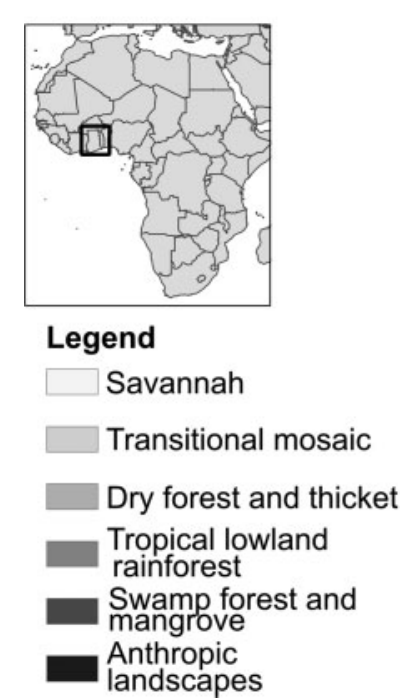

Figure 2. Major vegetation types of western Africa relative to Lake Bosumtwi (Ghana). Vegetation classifications follow White (1983).

\subsection{MATERIALS AND METHODS}

\subsubsection{Study site}

Lake Bosumtwi ( $06^{\circ} 30^{\prime} 06.04$ " N, 0124' 52.14" W, 97 metres above sea level; Figure 2) was formed by a meteorite impact $c .1$ million years ago and is a hydrologically closed system (Koeberl et al. 1998). The International Continental Scientific Drilling Program (ICDP) Lake Bosumtwi drilling project extracted a c. $295 \mathrm{~m}$ sediment core from the centre of the basin in 2004 (named BOS04-5B) (Koeberl et al. 2005; Koeberl et al. 2007).

Lake Bosumtwi lies within the seasonal migration path of the Intertropical Convergence Zone (ITCZ) and moisture is also delivered to the site by the West African monsoon (Nicholson 2009). This climate configuration results in a strong gradient of decreasing precipitation from south to north across western Africa. Concomitant with the climate gradient is a vegetation gradient which means that today Lake Bosumtwi is surrounded by semi-deciduous forest, with evergreen forest to the south, and savanna to the north (Figure 2; White 1983). Analysis of ancient pollen contained within the BOS04-5B core revealed multiple transitions between forest and savanna vegetation during the last c. 520,000 years which have been linked to multimillennial, orbitally forced, climate changes (Miller and Gosling 2014; Miller et al. 2016). In this study, two short $(c .5 \mathrm{~m})$ sections of the core, in which vegetation transitions had previously been identified, were sub-sampled for further palaeoecological analysis to explore the impact of shorter-term landscape-scale process on past vegetation dynamics (Figure 3; Gosling et al. 2021).

\subsubsection{Chronological control}

Previously published radiometric dates indicate that the meteorite which formed Lake Bosumtwi impacted the Earth c. $1.07 \pm 0.05$ million years ago (Koeberl et al. 1998). Subsequent sediment 


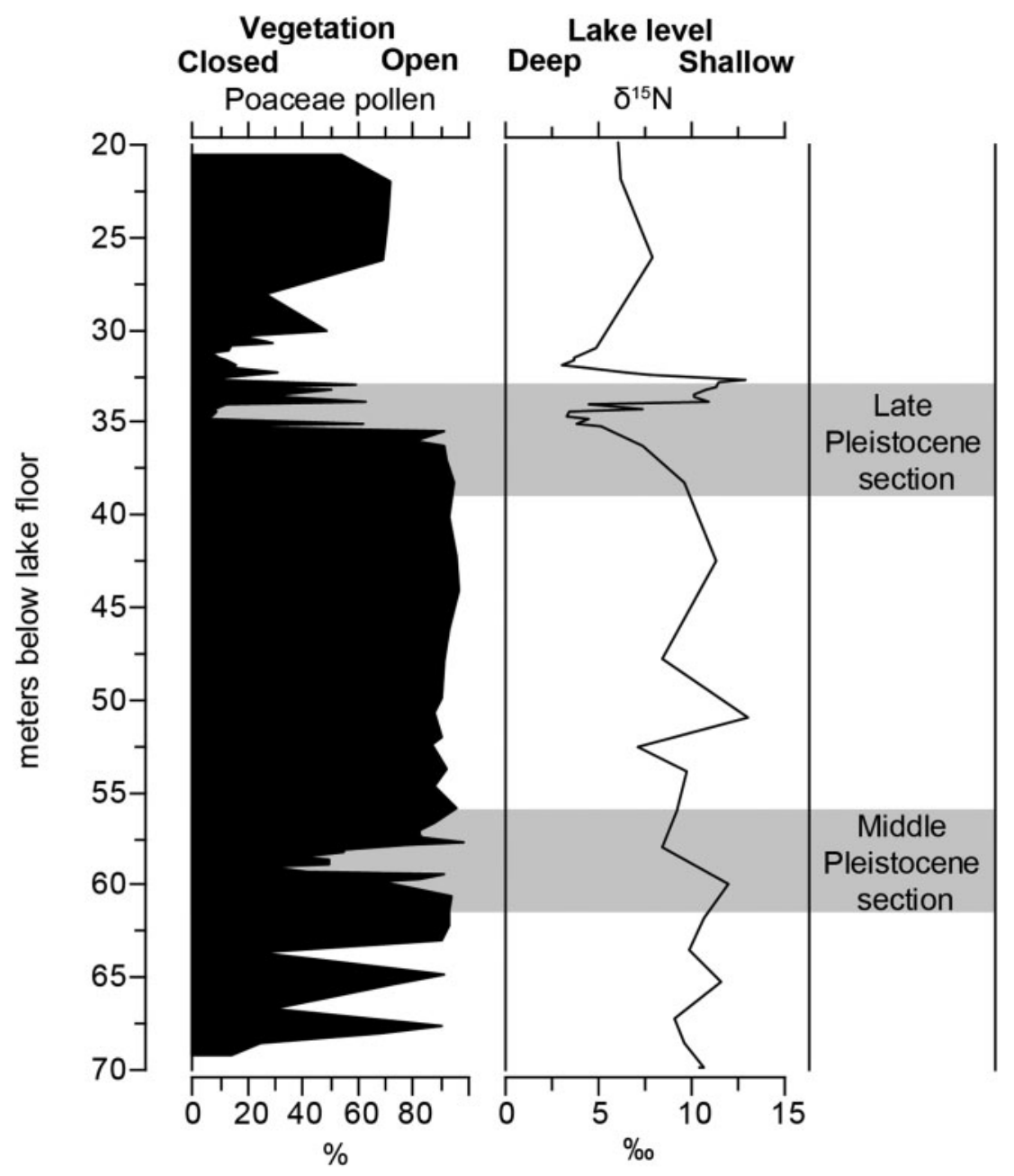

Figure 3. Position of the two sections focused on in this study (grey bars) from Lake Bosumtwi relative to previous palaeoecological work (modified from Miller et al. 2016).

accumulation through the core has been constrained by radiocarbon, U-series and optically stimulated luminance dating (Shanahan et al. 2013a). The two sections of the BOS04-5B core focused on here were recovered from 61.25-56.05 and 38.85-33.45 metres below lake floor (mblf) (Figure 3). Based on the radiometric dating these two sections were likely deposited during the Middle Pleistocene (c. 200,000 years ago) and Late Pleistocene (c. 100,000 years ago) respectively (Miller et al. 2016).

Previous studies into sediment deposition within Lake Bosumtwi indicated that the lightdark couplets of laminations within the sediments likely represent seasonal cycles (Shanahan et al. 2013b). Therefore, to gain a minimum estimate of the timescale over which these sections were deposited, the number of laminations within each section was counted on the basis that the sediment core images were included in the initial core descriptions. 


\subsubsection{Palaeoecological analysis}

Twenty sub-samples were prepared for palaeoecological analysis across each of the two sections using standard techniques including density separation, acetolysis and sieving at $180 \mu \mathrm{m}$ (Moore et al. 1991). An exotic marker (Lycopodium) was added to each sample to allow the concentration of microscopic remains to be calculated (Stockmarr 1971); University of Lund, batch \#483216, containing 18,583 grains $\pm 4.1 \%$. Each sub-sample was analysed for the concentration of Poaceae pollen, Sporormiella, and micro-charcoal $(<180 \mu \mathrm{m})$; identifications followed Gosling et al. (2013), van Geel and Aptroot (2006), and Whitlock and Larsen (2001) respectively. Phytoliths were also present in the prepared slides. Phytolith concentration from the same sub-samples were analysed across the Middle Pleistocene section; phytolith identifications were based on Piperno (2006).

\subsubsection{Statistical analysis and data presentation}

To assess the robustness of the palaeoecological datasets $95 \%$ confidence intervals were calculated (following Maher 1981). Bayesian Change Point (BCP) analysis (Barry and Hartigan 1993), which determines if there is a significant change in the mean of the variable at a given point in a time series, was used on: (i) Sporormiella (herbivore) concentration, and (ii) micro-charcoal (fire) concentration data. The posterior probabilities of the BCP analysis indicated the likelihood of significant change of those variables at each time step sampled (Barry and Hartigan 1993; Blois et al. 2011). Where the posterior probability of the BCP analysis exceeded 0.8 for Sporormiella or charcoal, a zone boundary was defined, indicating a significant change in herbivory or fire activity. Data were plotted using C2 (Juggins 2005).

\subsection{RESULTS}

Previously published radiometric dating indicates that the two sections studied here were deposited during the Middle and Late Pleistocene (Figure 3; Shanahan et al. 2013a). The results of the younger section are presented in the upper panel (Figure 4A) and the results of the older section are presented in the lower panel (Figure 4B).

\subsubsection{Lamination counting}

Approximately 1200 light-dark couplets of laminations were identified in the Middle Pleistocene section; however, no laminations could be identified in three parts of the section at: 60.25 59.85, 58.65-58.45, and 57.05-56.85 mblf (Figure 4B). Approximately 750 light-dark couplets of laminations were identified for the Late Pleistocene section; however, no laminations could be identified between 34.45 and 33.45 mblf (Figure 4A).

\subsubsection{Palaeoecological analysis}

For the Middle Pleistocene section two abrupt changes in vegetation consuming processes were detected by the BCP analysis at 59.25 (micro-charcoal) and 56.65 (Sporormiella) mblf defining three zones (Zones i, ii, and iii; Figure 4B). Within Zone i Poaceae pollen occurs in high concentrations (mean of 38,000 grains $/ \mathrm{cm}^{3}$ ), Poaceae phytoliths, tree phytoliths and micro-charcoal are ever present but are highly variable in concentration (1100-46,000 Poaceae phytoliths $/ \mathrm{cm}^{3}, 28,000-240,000$ tree phytoliths $/ \mathrm{cm}^{3}$, and $250,000-1,600,000$ fragments $/ \mathrm{cm}^{3}$ ), 
and Sporormiella is absent. In Zone ii Poaceae pollen is continually present at medium concentration (mean 26,000 grains $/ \mathrm{cm}^{3}$ ), Poaceae phytoliths, tree phytoliths and micro-charcoal are usually present and highly variable in concentration (4000-127,000 Poaceae phytoliths $/ \mathrm{cm}^{3}, 0$ 360,000 tree phytoliths $/ \mathrm{cm} 3,199,000-6,194,000$ fragments $\left./ \mathrm{cm}^{3}\right)$, and Sporormiella is absent. In Zone iii Poaceae pollen and phytoliths occur at high concentrations (mean 35,000 grains $/ \mathrm{cm}^{3}$ and 34,000 phytoliths $/ \mathrm{cm}^{3}$ respectively), but tree phytoliths are absent; micro-charcoal is variable $\left(395,000-978,000\right.$ fragments $\left./ \mathrm{cm}^{3}\right)$, and Sporormiella is continually present (395-1133 spores $\left./ \mathrm{cm}^{3}\right)$.

For the Late Pleistocene section two abrupt changes in vegetation consuming processes were detected by the BCP analysis at 36.45 (Sporormiella and micro-charcoal) and 34.25 (Sporormiella) mblf defining three zones (Zones I, II, and III; Figure 4A). Within Zone I Poaceae pollen $\left(17,000\right.$ grains $\left./ \mathrm{cm}^{3}\right)$, Sporormiella (mean 1200 spores $/ \mathrm{cm}^{3}$ ), and micro-charcoal (mean 291,000 particles $/ \mathrm{cm}^{3}$ ) are all relatively highly abundant within the section. In Zone II Poaceae pollen (mean 14,000 grains $/ \mathrm{cm}^{3}$ ) are abundant, while Sporormiella and micro-charcoal vary widely (0-8400 spores $/ \mathrm{cm}^{3}$ and 15,000-496,000 fragments $/ \mathrm{cm}^{3}$ respectively). In Zone III Poaceae pollen (mean 2700 grains $/ \mathrm{cm}^{3}$ ) and micro-charcoal (mean 4400 fragments $/ \mathrm{cm}^{3}$ ) are relatively low, while Sporormiella varies (0-4000 spores $\left./ \mathrm{cm}^{3}\right)$ in concentration.

\subsection{DISCUSSION}

\subsubsection{Timescales of deposition}

Radiometric dating indicates that the Middle Pleistocene section was deposited c. 200,000 years ago during a period of high eccentricity in the Earth's orbital cycle (Miller et al. 2016). This orbital configuration of northern hemisphere insolation maximum, during a precession minimum and an eccentricity maximum, extenuates seasonal variations at Lake Bosumtwi $\left(6^{\circ} \mathrm{N}\right)$. Therefore, this period of time likely represents ecosystem functioning under high seasonal stress, and a consistently low level of Lake Bosumtwi during this period (Figure 2). The Late Pleistocene section is indicated to have been deposited c. 100,000 years ago as part of the longer transition out of the last interglacial period and includes a period of relatively higher lake levels (Figure 2).

Lamination counting within the two sections revealed 1200 light-dark couplets in $5.2 \mathrm{~m}$ of sediment in the Middle Pleistocene section, and 750 light-dark couplets in $5.4 \mathrm{~m}$ in the Late Pleistocene section. These counts were derived from visual inspection of digital core scan images and consequently likely represent an under-estimate of the true number of bands present because some may not have been captured in the digital imagery of the core surface. To reveal all bands, and develop a robust internal chronology, further analysis of the sediments in thin section is required. The preliminary analysis presented here shows this is a promising line of investigation and, based on the visible bands, it can be roughly estimated that the period of deposition represented by each of these sections is more than 1000 years. The relatively higher number of bands in the older section could be related to the enhanced seasonality and lower sedimentation rates during this period.

\subsubsection{Evidence for green, brown and black worlds}

Fire (charcoal) was ever present, and highly abundant, in the Middle Pleistocene section (Zone i, ii and iii in Figure 4B), while herbivores (Sporormiella) only appear in the uppermost samples (Zone iii in Figure 4B). The first transition (Zone i to Zone ii) is defined by a change in fire activity that is coincident with a slight drop in the average concentration of Poaceae pollen, however, no directional change in the concentration of Poaceae or tree phytoliths is discernible at this time. This suggests that vegetation state did not change significantly. The second transition 

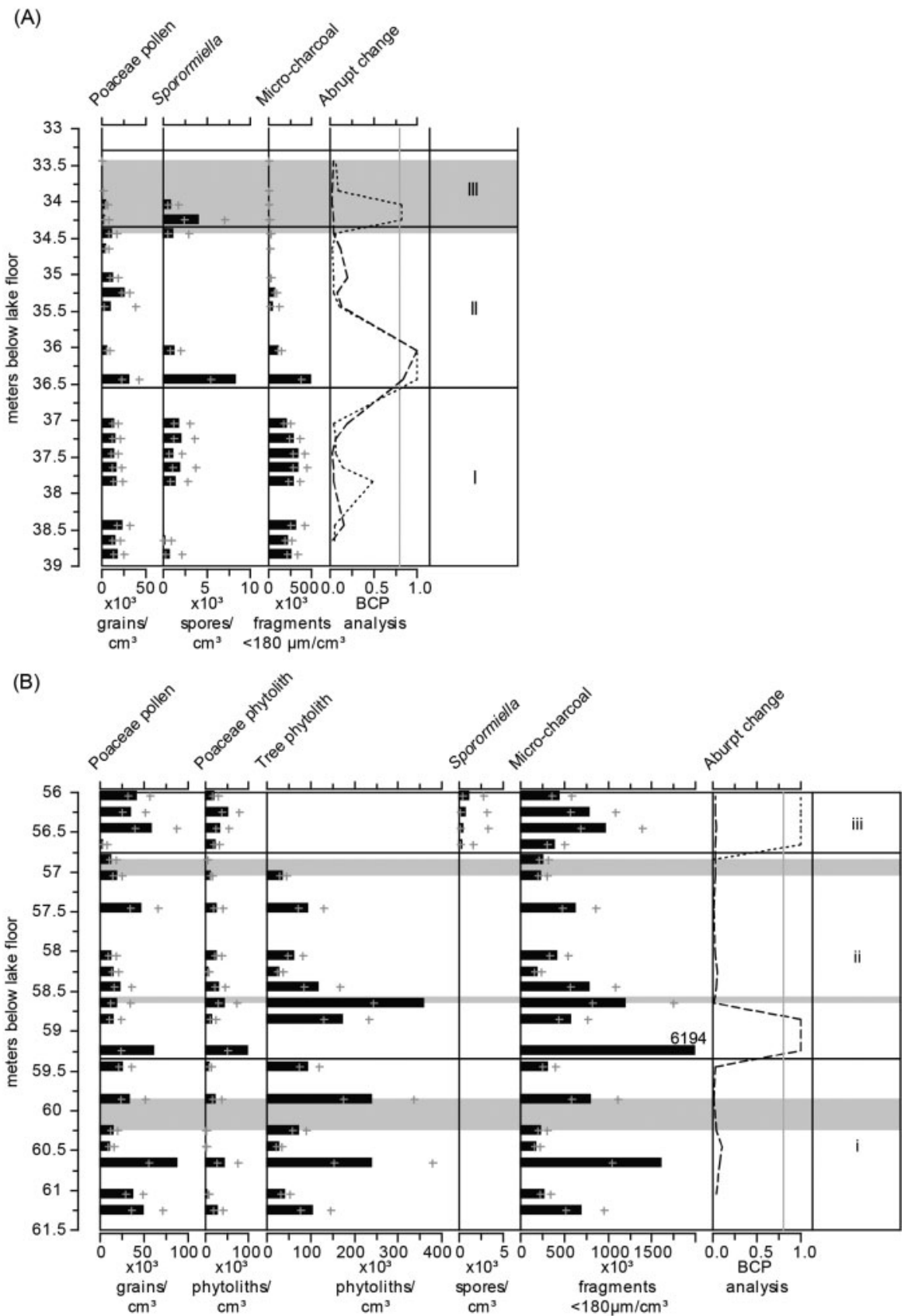

Figure 4. Palaeoecological diagram from two portions of the Lake Bosumtwi (BOS05-3B) sedimentary record: (A) Late Pleistocene (c. 39.0-33.0 mblf), and (B) Middle Pleistocene (c. 56.0-61.5 mblf). Dark grey plus symbols indicate upper and lower confidence intervals $(95 \%)$. Horizontal light grey bands indicate portions of the sediment

without laminations. For 'Abrupt change' curves: black dotted line indicates BCP analysis of Sporormiella concentration data, black dashed line indicated BCP analysis of micro-charcoal concentration data, vertical solid grey line indicates 0.8 significance threshold. In the case of one sample, at $59.25 \mathrm{mblf}$, the concentration of charcoal fragments exceeds the scales shown and the upper value is indicated numerically. Raw data available from Gosling et al. (2021). 
(Zone ii to Zone iii) is defined by the appearance of herbivores, and is associated with the loss of tree phytoliths and the rise of Poaceae pollen and phytolith concentrations. This suggests that increased herbivory did diminish, or alter, the woody component of the vegetation. Throughout this section the high concentration of Poaceae (indicated by both pollen and phytoliths) with a variable woody component (indicated by the tree phytoliths) suggests that the landscape around Lake Bosumtwi during this short snapshot of the Middle Pleistocene was similar to the open vegetation found in the forest-savannah transition zone c. $250 \mathrm{~km}$ north of Lake Bosumtwi today (Julier et al. 2018), rather than the closed vegetation found close to the site today (Julier et al. 2019; Figure 1). Today in the transition zone fires during the dry season (November-March) limit juvenile establishment and sapling recruitment (Armani et al. 2018). The enhanced seasonality during this part of the Middle Pleistocene likely resulted in two prolonged and intense dry seasons during which burning could have occurred. The enhanced seasonality likely meant that fire was an even greater consumer of vegetation then than it is today in the transition zone, suggesting that this entire section likely represents 'black' world open vegetation.

Fire activity and herbivory both change through the Late Pleistocene section (Figure 4A). The first transition (Zone I to II) sees first a spike and then a persistent decline in both herbivory and fire activity. Prior to the spike (Zone I) herbivory levels and fire activity are relatively high and stable, and this is mirrored in the Poaceae concentration. After the spike (Zone II) herbivory and fire activity fluctuate, and are periodically absent, which is coincident with a slight drop in Poaceae concentration. Sporormiella and micro-charcoal concentrations relative to the Middle Pleistocene 'black' world section are higher and lower respectively. This suggests that in the Late Pleistocene section herbivores likely played a relatively more important role in determining vegetation structure. Therefore, it can be tentatively suggested that where Sporormiella is abundant a 'brown' world persisted. Although it should be noted that both herbivory and fires were clearly present and no doubt both helped to maintain the vegetation openness. Furthermore, it seems that the role of both herbivory and fire as consumers of vegetation (promoting higher Poaceae concentration and inferred openness) is diminishing through Zones I and II. The concomitant decline in consumers and Poaceae perhaps suggests a move from a consumer controlled stable state, towards a more closed canopy 'green(er)' world. The second transition (Zone II to III) is defined by a rise in herbivory, and is coincident with a drop (to near absence) in fire activity, low concentrations of Poaceae pollen, a sedimentological change (loss of laminations), and a drop in lake level (Figure 2). It is consequently unclear if the lower Poaceae pollen concentration (and inferred decreased openness) observed in Zone III are a direct result of diminishing numbers of herbivores and fire activity leading us into a 'green' world, or if other, possibly climatological or taphonomic controls are responsible.

\subsubsection{Insights into past vegetation states in tropical western Africa}

The preliminary data from the two sections examined here provide evidence for the presence of, and switches between, green, brown and black worlds in tropical western Africa during the Middle and Late Pleistocene. It is also apparent that different combinations of herbivores and fire in the landscape resulted in different degrees of openness (stable states) persisting. It seems likely that the background climatic configuration and seasonality played a significant role in determining the relative importance of these processes; an observation that aligns with modern studies which indicate that fire prevalence is most strongly linked to previous years' rainfall (van Wilgen et al. 2004). The presence of both herbivores and fire within the landscape is coincident with elevated concentration of Poaceae pollen and phytoliths in line with expectations from modern studies that suggest these vegetation consumers promote more open ecosystems (Bond 2005; Bond 2019; Warman and Moles 2009). The timescales over which the green, brown and black alternative 'stable states' persisted appears to be at least on the order of centuries to millennia. 
It can be tentatively suggested that transitions between green, brown and black worlds occur over decades to centuries; however, it should also be noted that both gradual transitions seem to exist (i.e. in the Late Pleistocene section herbivory, fire activity and Poaceae all decline in a step wise fashion) as well as abrupt shifts (i.e. in the Middle Pleistocene section herbivory appears and tree phytoliths disappear at the same time). The different modes of transition suggest a complex series of interactions are responsible for initiating and driving vegetation dynamics during both time windows. This finding is in line with more recent data from savanna in eastern African that suggest that over the last 1400 years periodic fluctuations in woody cover driven by landscape processes are the rule, not the exception (Gillson 2004). Complex landscape scale processes have also been observed to be important over longer timescales during the transition out of the last interglacial period at Lake Bosumtwi (Shanahan et al. 2016) and over shorter timescales in the modern forest-savanna transition zone to the north (Ametsitsi et al. 2020). These findings emphasize the need for further empirical data to contextualize the role of processes, such as herbivory and fire activity, in determining vegetation states in Africa across space and through time.

\subsubsection{Future perspectives}

To determine the relative importance of herbivory and fire as consumers of vegetation, and how this changes through time, at Lake Bosumtwi further research is required. Firstly, a robust internal chronology should be established through detailed examination of the nature and frequency of the laminations, and secondly further details should be extracted from the palaeoecological and palaeoclimatic record. Specifically, detailed pollen and phytolith analyses are required at a higher temporal resolution to characterize trajectories of vegetation change. These vegetation data need to be supported by: (i) further charcoal analyses (micro- and macro-charcoal and charcoal chemistry) to reveal the biomass consumption and temperature of burning (Gosling et al. 2019; Whitlock and Larsen 2001), (ii) examination of a full suite of coprophilous fungal spores (not just Sporormiella) to provide insights into changing animal assemblages (Loughlin et al. 2018; van Geel and Aptroot 2006), and (iii) further independent evidence for climatic change should be sought, including further $\delta^{15} \mathrm{~N}$ analysis to determine changes in moisture balance (Talbot 2001; Talbot and Johannessen 1992), and pollen chemical analysis to identify fluctuations in solar irradiance (Jardine et al. 2016; Jardine et al. 2021).

\subsection{CONCLUSIONS}

The examination of Middle and Late Pleistocene sections of the Lake Bosumtwi sediment core provide evidence for, and switches between, 'green', 'brown' and 'black' worlds. The different coloured worlds (alternative stable states) each seem to persist for hundreds to thousands of years. The addition, and subtraction, of herbivory and fire activity from the landscape around Lake Bosumtwi seems to have resulted in vegetation change occurring in both an abrupt and complex gradual fashion over decades to centuries. Although the mechanisms behind the changes in herbivory and fire activity remain largely ambiguous, it seems likely that seasonality modulated by orbital forcing plays a strong role in governing fire activity. To further our understanding of the persistence of, and transition between, alternative stable states around Lake Bosumtwi we now need to improve the chronological control, enhance our sampling resolution, and expand the range of proxies analysed to provide a comprehensive insight into past ecosystem dynamics. Armed with these data we will be able to better anticipate the impact of projected climate changes for tropical western Africa. 


\section{ACKNOWLEDGEMENTS}

Palaeoecological data were generated by ZG and ER as part of their BSc Biology dissertation projects supervised by WDG and CNHM. CSM and AJ assisted with the pollen identifications. WG wrote the manuscript with contributions from all authors.

\section{DATA AVALIABILITY}

All data presented in this manuscript can be downloaded from DOI: $10.6084 / \mathrm{m} 9$.figshare. 127 38131

\section{REFERENCES}

Ametsitsi, G.K., van Langevelde, F., Logah, V., Janssen, T., Medina-Vega, J.A., Issifu, H., Ollivier, L., den Hartogh, K., Adjei-Gyapong, T. and Adu-Bredu, S., 2020, Fixed or mixed? Variation in tree functional types and vegetation structure in a forest-savanna ecotone in West Africa. Journal of Tropical Ecology 36, pp. 133-149, 10.1017/S0266467420000085.

Armani, M., van Langevelde, F., Tomlinson, K.W., Adu-Bredu, S., Djagbletey, G.D. and Veenendaal, E.M., 2018, Compositional patterns of overstorey and understorey woody communities in a forest-savanna boundary in Ghana. Plant Ecology and Diversity 11, pp. 451-463, 10.1080/17550874.2018.1539133.

Barry, D. and Hartigan, J.A., 1993, A Bayesian analysis for change point problems. Journal of the American Statistical Association 88, pp. 309-319, 10.2307/2290726.

Blois, J.L., Williams, J.W.J., Grimm, E.C., Jackson, S.T. and Graham, R.W., 2011, A methodological framework for assessing and reducing temporal uncertainty in paleovegetation mapping from late-Quaternary pollen records. Quaternary Science Reviews 30, pp. 1926-1939, 10.1016/j.quascirev.2011.04.017.

Bond, W.J., 2019, Open Ecosystems: Ecology and Evolution Beyond the Forest Edge (Oxford: Oxford University Press).

Bond, W.J., 2005, Large parts of the world are brown or black: A different view on the 'Green World' hypothesis. Journal of Vegetation Science 16, pp. 261-266, 10.1658/1100-9233(2005) 016[0261:LPOTWA]2.0.CO;2.

Enslin, B., Potgieter, A., Biggs, H. and Biggs, R., 2000, Long term effects of fire frequency and season on the woody vegetation dynamics of the Sclerocarya birrea/Acacia nigrescens savanna of the Kruger National Park. Koedoe 43, pp. 27-37, 10.4102/koedoe.v43i1.206.

Gillson, L., 2004, Testing non-equilibrium theories in savannas: 1400 years of vegetation change in Tsavo National Park, Kenya. Ecological Complexity 1, pp. 281-298, 10.1016/j.ecocom. 2004.06.001.

Gosling, W.D., McMichael, C.N.H., Groenewoud, Z., Roding, E., Miller, C.S. and Julier, A.C.M., 2021, Data from: Preliminary evidence for green, brown and black worlds in tropical western Africa during the Middle and Late Pleistocene. FigShare Data Repository, 10.6084/ m9.figshare.12738131.

Gosling, W.D., Cornelissen, H. and McMichael, C.N.H., 2019, Reconstructing past fire temperatures from ancient charcoal material. Palaeogeography, Palaeoclimatology, Palaeoecology 520, pp. 128-137, 10.1016/j.palaeo.2019.01.029.

Gosling, W.D., Miller, C.S. and Livingstone, D.A., 2013, Atlas of the tropical West African pollen flora. Review of Palaeobotany and Palynology 199, pp. 1-135, 10.1016/j.revpalbo. 2013.01.003. 
Ivory, S.J. and Russell, J., 2016, Climate, herbivory, and fire controls on tropical African forest for the last 60ka. Quaternary Science Reviews 148, pp. 101-114, 10.1016/j.quascirev.2016. 07.015.

Jardine, P.E., Fraser, W.T., Lomax, B.H., Sephton, M.A., Shanahan, T.M., Miller, C.S. and Gosling, W.D., 2016, Pollen and spores as biological recorders of past ultraviolet irradiance. Scientific Reports 6, article 39269, 10.1038/srep39269.

Jardine, P.E., Hoorn, C., Beer, M.A.M., Barbolini, N., Woutersen, A., Bogota-Angel, G., Gosling, W.D., Fraser, W.T., Lomax, B.H., Huang, H., Sciumbata, M., He, H. and Dupont-Nivet, G., 2021, Sporopollenin chemistry and its durability in the geological record: An integration of extant and fossil chemical data across the seed plants. Palaeontology. 10.1111/pala.12523

Juggins, S., 2005, C2 Program version 1.5 (Newcastle upon Tyne: University of Newcastle).

Julier, A.C.M., Jardine, P.E., Adu-Bredu, S., Coe, A.L., Duah-Gyamfi, A., Fraser, W.T., Lomax, B.H., Malhi, Y., Moore, S., Owusu-Afriyie, K. and Gosling, W.D., 2018, The modern pollenvegetation relationships of a tropical forest-savannah mosaic landscape, Ghana, West Africa. Palynology 42, pp. 324-338, 10.1080/01916122.2017.1356392.

Julier, A.C.M., Jardine, P.E., Adu-Bredu, S., Coe, A.L., Fraser, W.T., Lomax, B.H., Malhi, Y., Moore, S. and Gosling, W.D., 2019, Variability in modern pollen rain from moist and wet tropical forest plots in Ghana, West Africa. Grana 58, pp. 45-62, 10.1080/00173134.2018.15 10027.

King, J., Moutsinga, J. and Doufoulon, G., 1997, Conversion of anthropogenic savanna to production forest through fire-protection of the forest-savanna edge in Gabon, Central Africa. Forest Ecology and Management 94, pp. 233-247, 10.1016/S0378-1127(96)03925-4.

Koeberl, C., Peck, J., King, J.W., Milkereit, B., Overpeck, J.T. and Scholz, C.A., 2005, The ICDP Lake Bosumtwi drilling project: A first report. Scientific Drilling 1, pp. 23-27, 10.5194/sd-123-2005.

Koeberl, C., Milkereit, B., Overpeck, J.T., Scholz, C.A., Amoako, P.Y.O., Boamah, D., Danuor, S.K., Karp, T., Kueck, J., Hecky, R.E., King, J.W. and Peck, J.A., 2007, An international and multidisciplinary drilling project into a young complex impact structure: The 2004 ICDP Bosumtwi Crater Drilling Project - An overview. Meteoritics and Planetary Science 42, pp. 483-511, 10.1111/j.1945-5100.2007.tb01057.x.

Koeberl, C., Reimold, W., Blum, J. and Chamberlain, C.P., 1998, Petrology and geochemistry of target rocks from the Bosumtwi impact structure, Ghana, and comparison with Ivory Coast tektites. Geochimica et Cosmochimica Acta 62, pp. 2179-2196, 10.1016/S00167037(98)00137-9.

Loughlin, N.J.D., Gosling, W.D. and Montoya, E., 2018, Identifying environmental drivers of fungal non-pollen palynomorphs in the montane forest of the eastern Andean flank, Ecuador. Quaternary Research 89, pp. 119-133, 10.1017/qua.2017.73.

Maher, J.L.J., 1981, Statistics for microfossil concentration measurements employing samples spiked with marker grains. Review of Palaeobotany and Palynology 32, pp. 153-191, 10.1016/0034-6667(81)90002-6.

May, R.M., 1977, Thresholds and breakpoints in ecosystems with a multiplicity of stable states. Nature 269, pp. 471-477, 10.1038/269471a0.

Miller, C.S. and Gosling, W.D., 2014, Quaternary forest associations in lowland tropical West Africa. Quaternary Science Reviews 84, pp. 7-25, 10.1016/j.quascirev.2013.10.027.

Miller, C.S., Gosling, W.D., Kemp, D.B., Coe, A.L. and Gilmour, I., 2016, Drivers of ecosystem and climate change in tropical West Africa over the past $\sim 540000$ years. Journal of Quaternary Science 31, pp. 671-677, 10.1002/jqs.2893.

Moore, P.D., Webb, J.A. and Collinson, M.E., 1991, Pollen Analysis, 2nd edition (Oxford: Blackwell Scientific).

Nicholson, S.E., 2009, A revised picture of the structure of the "monsoon" and land ITCZ over West Africa. Climate Dynamics 32, pp. 1155-1171, 10.1007/s00382-008-0514-3. 
Piperno, D.R., 2006, Phytoliths: A Comprehensive Guide for Archaeologists and Paleoecologists (Lanham: Alta Mira Press).

Riginos, C., Porensky, L.M., Veblen, K.E., Odadi, W.O., Sensenig, R.L., Kimuyu, D., Keesing, F., Wilkerson, M.L. and Young, T.P., 2012, Lessons on the relationship between livestock husbandry and biodiversity from the Kenya Long-term Exclosure Experiment (KLEE). Pastoralism: Research, Policy and Practice 2, 10.1186/2041-7136-2-10, article 10.

Roques, K.G., O'Connor, T.G. and Watkinson, A.R., 2001, Dynamics of shrub encroachment in an African savanna: Relative influences of fire, herbivory, rainfall and density dependence. Journal of Applied Ecology 38, pp. 268-280, 10.1046/j.1365-2664.2001.00567.x.

Rucina, S.M., Muiruri, V.M., Kinyanjui, R.N., McGuiness, K. and Marchant, R., 2009, Late Quaternary vegetation and fire dynamics on Mount Kenya. Palaeogeography, Palaeoclimatology, Palaeoecology 283, pp. 1-14, 10.1016/j.palaeo.2009.08.008.

Sankaran, M., Ratnam, J. and Hanan, N., 2008, Woody cover in African savannas: The role of resources, fire and herbivory. Global Ecology and Biogeography 17, 236-245, 10.1111/j.14668238.2007.00360.x.

Scheffer, M., Carpenter, S., Foley, J.A., Folke, C. and Walker, B., 2001, Catastrophic shifts in ecosystems. Nature 413, pp. 591-596, 10.1038/35098000.

Shanahan, T.M., Peck, J.A., McKay, N., Heil, C.W., King, J., Forman, S.L., Hoffmann, D.L., Richards, D.A., Overpeck, J.T. and Scholz, C., 2013a, Age models for long lacustrine sediment records using multiple dating approaches - An example from Lake Bosumtwi, Ghana. Quaternary Geochronology 15, pp. 47-60, 10.1016/j.quageo.2012.12.001.

Shanahan, T.M., McKay, N., Overpeck, J.T., Peck, J.A., Scholz, C., Heil, C.W. and King, J., 2013b, Spatial and temporal variability in sedimentological and geochemical properties of sediments from an anoxic crater lake in West Africa: Implications for paleoenvironmental reconstructions. Palaeogeography, Palaeoclimatology, Palaeoecology 374, pp. 96-109, 10.1016/j.palaeo.2013.01.008.

Shanahan, T.M., Hughen, K.A., McKay, N.P., Overpeck, J.T., Scholz, C.A., Gosling, W.D., Miller, C.S., Peck, J.A., King, J.W. and Heil, C.W., 2016, $\mathrm{CO}_{2}$ and fire influence tropical ecosystem stability in response to climate change. Scientific Reports 6, 29587, 10.1038/srep29587.

Staver, A.C., Bond, W.J., Stock, W.D., van Rensburg, S.J. and Waldram, M.S., 2009, Browsing and fire interact to suppress tree density in an African savanna. Ecological Applications 19, pp. 1909-1919, 10.1890/08-1907.1.

Stebbing, E.P., 1937, The Forests of West Africa and the Sahara (London and Edinburgh: W. and R. Chambers Ltd.).

Stockmarr, J., 1971, Tablets with spores used in absolute pollen analysis. Pollen et Spore XIII, pp. 615-621.

Talbot, M.R., 2001, Nitrogen isotopes in palaeolimnology. In Tracking Environmental Change Using Lake Sediments. Volume 2. Physical and Geochemical Methods edited by Last, W.M. and Smol, J.P., (Dordrecht, Boston and London: Kluwer Academic Press), pp. 401-439.

Talbot, M.R. and Johannessen, T., 1992, A high resolution palaeoclimatic record for the last 27500 years in tropical West Africa from the carbon and nitrogen isotopic composition of lacustrine organic matter. Earth and Planetary Science Letters 110, pp. 23-37, 10.1016/0012821X(92)90036-U.

van Geel, B. and Aptroot, A., 2006, Fossil ascomycetes in Quaternary deposits. Nova Hedwigia 82, pp. 313-329, 10.1127/0029-5035/2006/0082-0313.

van Wilgen, B., Govender, N., Biggs, H., Ntsala, D. and Funda, X., 2004, Response of savanna fire regimes to changing fire-management policies in a large African national park. Conservation Biology 18, pp. 1533-1540, 10.1111/j.1523-1739.2004.00362.x.

Warman, L. and Moles, A.T, 2009, Alternative stable states in Australia's wet tropics: A theoretical framework for the field data and a field-case for the theory. Landscape Ecology 24, pp. 1-13, 10.1007/s10980-008-9285-9. 
White, F., 1983, The Vegetation of Africa: A Descriptive Memoir to Accompany the Unesco/AETFAT/UNSO vegetation map of Africa (UNESCO).

Whitlock, C. and Larsen, C., 2001, Charcoal as a fire proxy. In Tracking Environmental Change Using Lake Sediments Volume 3: Terrestrial, Algal and Siliceous Indicators, edited by Smol, J.P., Birks, H.J.B., and Last, W.M., (Dordrecht, Boston and London: Kluwer Academic Press), pp. $75-98$. 


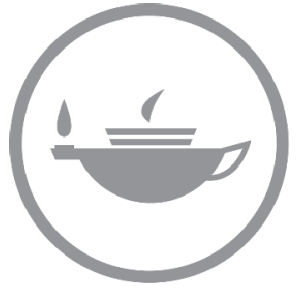

Taylor \& Francis Taylor \& Francis Group http://taylorandfrancis.com 